\title{
CORRELATION BET WEEN TIMI RISK SCORE AND CLINICAL OUTCOME IN PATIENTS WITH UNSTABLE ANGINA PECTORIS
}

Zorica Savovic, Violeta Iric-Cupic, Goran Davidovic

Clinic of Cardiology, Clinical Center Kragujevac, Kragujevac, Serbia

\author{
KORELACIJA TIMI RISK SKORA I KLINIČKOG ISHODA \\ KOD PACIJENATA SA NESTABILNOM ANGINOM PEKTORIS \\ Zorica Savović, Violeta Irić-Ćupić, Goran Davidović \\ Klinika za kardiologiju, Klinički centar Kragujevac, Kragujevac, Srbija
}

\begin{abstract}
Given Taking that the TIMI score is a major predictor of $M A C E$, this study aimed to determine the value of the TIMI risk score in predicting poor outcomes (death, myocardial infarction, recurrent pain) in patients presenting with unstable angina pectoris in short-term observation. A total of 107 patients with APns were examined at the Clinical Centre Kragujevac and were included in the investigation. The TIMI score was determined on the first day of hospitalization. During hospitalization, the following factors were also observed: troponin, ECG evolution, further therapy (pharmacologic therapy and/or emergency PCI or $C A B G)$, age, hypertension and hyperlipidaemia. The low-risk group (TIMI O - 2) included $30.8 \%$ of patients, whereas $47.6 \%$ of patients were in the intermediate-risk group (TIMI 3 -4), and $21.5 \%$ of patients were in the high-risk group (TIMI 5 - 7). Good outcomes (without adverse event) and poor outcomes (death, myocardial infarction, and recurring chest pain) were dependent on the TIMI risk score. The increase in TIMI risk score per one unit increased the risk of a poor outcome by 54\%. Troponin and TIMI risk score were positively correlated. Our results suggest that the TIMI risk score may be a reliable predictor of a poor outcome (MACE) during the short-term observation of patients with APns. Moreover, patients identified as high-risk benefit from early invasive PCI, enoxaparin and Gp IIb/IIIa inhibitors. Thus, routine use of the TIMI risk score at admission may reduce the number of patients not recognized as high-risk.
\end{abstract}

Keywords: TIMI risk score, unstable angina pectoris, poor outcome

\section{SAŽETAK}

Ako uzmemo u obzir da je TIMI risk skor glavni prediktor MACE, istraživanje je imalo za cilj da identifikuje vrednosti TIMI risk skora koji mogu da predvide loš ishod (smrt, infarkt, rekurentni bol) kod pacijenata sa nestabilnom anginom pectoris u kratkoročnom praćenju. U ispitivanje je uključeno 107 pacijenata primljenih u Klinički centar Kragujevac kao APns. TIMI risk skor je utvrđivan prvog dana hospitalizacije. Tokom hospitalizacije praćeni su i sledeći faktori: troponin, ECG evolutivnost, dalja terapija (medikamentna terapija i/ili urgentni PCI, PCI, $C A B G)$, godine, hipertenzija $i$ hiperlipidemija. U grupi malog rizika (TIMI 0-2) je 30,8\% pacijenata, $47.6 \%$ pripadalo je umereno rizičnoj grupi (TIMI 3-4) a $21.5 \%$ je $u$ visoko rizičnoj grupi (TIMI 5-7). Dobar ishod (bez neželjenih događaja) $i$ loš ishod (smrt, infarkt $i$ rekurentni bol) su u zavisnosti od TIMI risk skora. Povećanje TIMI risk skora za jedan povećavao je rizik za loš ishod za 54\%. Troponin i TIMI risk skor su u pozitivnoj korelaciji. Naši rezultati ukazuju da TIMI risk skor moze biti dobar prediktor lošeg ishoda (MACE) za vreme kratkoročnog praćenja pacijenata sa APns. Pacijenti identifikovani kao visoko rizični imaju benefit od rane invazivne PCI, enoksaparina, GpIIb/IIIa. Rutinska upotreba TIMI risk skora u prijemnim ambulantama mogla bi redukovati broj pacijenata koji nisu prepoznati kao visokorizični.

Ključne reči: TIMI risk skor, nestabilna angina pectoris, loš rezultat. 


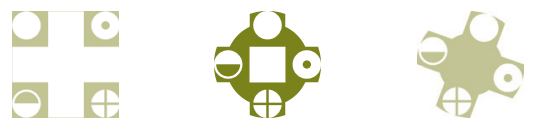

INTRODUCTION

Patients with APns/NSTEMI are a heterogeneous group who may have a good prognosis with the administration of conventional therapy if they belong to the lowrisk group; patients in the high-risk group require aggressive antithrombotic therapy and invasive procedures. The mortality in patients with APns is less than $1.7 \%$, whereas the mortality in patients with NSTEMI/STEMI is less than $5.1 \%$, which was determined by short-term observation within a period of 30 days. However, long-term observation showed a similar incidence of nonfatal events and increased mortality in patients with APns/NSTEMI. Risk stratification is of vital importance for isolating and monitoring patients in the high-risk group, as well as those whose condition shows the greatest improvement as a result of timely diagnostic and therapeutic measures (1).

HoweverTthe TIMI risk score highlights seven independent factors (based principally on risk factors): 1 . older than 65 years, 2. more than three risk factors for coronary artery disease, 3 . arteriographically documented coronary artery disease (50\% diameter stenosis), 4. denivelation of the ST-segment $\geq 0.5 \mathrm{~mm}$ on ECG, 5 . more than two episodes of angina during the last 24 hours, 6 . consumption of aspirin in the previous week and 7. higher marker levels for myocardial necrosis. The risk of death, myocardial infarction or emergency revascularization within 14 days of observation in patients with a risk score of 2 is $8.3 \%$, whereas it is $19.9 \%$ in patients with a risk score of 4 and $40.9 \%$ in patients with a risk score of 6-7. Thus, we conclude that $75 \%$ of patients (those with a TIMI risk score of three or more) benefit from invasive compared with conservative strategies, and from enoxaparin compared with heparin and from GP IIb/IIIa inhibitors compared with the use of placebo healing strategies $(2,3)$.

Given taking the above-mentioned findings, this study aimed to determine the value of the TIMI risk score with respect to MACE (death, myocardial infarction, recurrent pain) in the short-term observation of patients.

\section{MATERIALS AND METHODS}

\section{Study population}

This retrospective study included 107 patients recruited at the Clinic of Cardiology, Clinical Centre in Kragujevac, from August 2006 until the end of 2007.

\section{Protocol}

At admission and after hospitalization, all patients were diagnosed with unstable angina pectoris. All patients had their TIMI risk score determined at admission. During hospitalizsation, the following factors were also assessed: age, sex, risk factors (diabetes, hypertension, hyperlipidaemia, smoking, obesity and heredity), previous cardiovascular disease (myocardial infarction, PCI, CABG, PVD), ECG, CK, CK-MB, troponin I, CRP, cholesterol and
Table 1. Demographic characteristics of the patients

\begin{tabular}{|l|l|l|}
\hline \multicolumn{2}{|l|}{ Age $(X \pm S D(M e d ;$ min-max $))$} & $63.94 \pm 10.39(66 ; 37-83)$ \\
\hline \multirow{2}{*}{ Sex n (\%) } & male & $65(60.7 \%)$ \\
\cline { 2 - 3 } & female & $42(39.3 \%)$ \\
\hline
\end{tabular}

triglycerides. Troponin I, numerically presented and analysed on VIDAS instruments, was considered negative if it was less than 0.01 , borderline if it ranged from $0.01-0.1$, and high if it was more than 0.1. Other parameters were considered qualitatively normal or high. During their stay at the hospital, low-risk patients were given pharmacologic therapy, whereas emergent or invasive PCI was administered to patients in the high-risk group. Healing outcomes were registered for all patients fourteen days after hospitalization, where poor outcomes included death, myocardial infarction and recurrent chest pain.

Patients with secondary or post-infarction angina pectoris, as well as those with a troponin I $\geq 0.1$, were not included in the study.

Heterogeneous groups and the unavailability of an interventional cardiologist and medical ward for daily 24hour catheterization during the period of examination were obstacles during the study.

\section{Statistical analyses}

Statistical analysis was performed with SPSS 10.0 for Windows. The results are expressed as the mean \pm standard deviation (median). Data were analysed by standard statistical tests (c2-test, ANOVA, univariate binary logistic regression and multivariate binary logistic regression).

\section{RESULTS}

\section{Demographic characteristics}

The demographic characteristics of the patients are presented in Table 1. Overall, 60.7\% (65) of the investigated population was male, whereas $39.3 \%$ (42) was female. The average age of was approximately 64 (37-83 years of age).

\section{Distribution of risk factors}

The distribution of risk factors is shown in Table 2. Overall, 31.8\% (34) of patients had DM, 72.9\% (78) had HTA, $37.4 \%$ (40) had HLP, 37.4\% (40) were smokers, $6.5 \%$ (7) were obese, and $49.5 \%$ (53) had positive family anamnesis.

Table 2. Risk factors

\begin{tabular}{|l|l|l|l|}
\hline $\begin{array}{l}\mathbf{N}^{\mathbf{2}} \\
\text { Risk factor }\end{array}$ & Name & $\begin{array}{l}\text { Number of } \\
\text { patients }\end{array}$ & $\mathbf{\%}$ \\
\hline $\mathbf{1}$ & Diabetes & 34 & 31.8 \\
\hline $\mathbf{2}$ & Hypertension & 78 & 72.9 \\
\hline $\mathbf{3}$ & Hyperlipidaemia & 40 & 37.4 \\
\hline $\mathbf{4}$ & Smoking & 40 & 37.4 \\
\hline $\mathbf{5}$ & Obesity & 7 & 6.5 \\
\hline $\mathbf{6}$ & Heredity & 53 & 49.5 \\
\hline
\end{tabular}


Table 3. Previous cardiovascular disease

\begin{tabular}{|l|l|l|l|}
\hline $\begin{array}{l}\mathbf{N}^{\mathbf{2}} \\
\text { Risk factor }\end{array}$ & Name & $\begin{array}{l}\text { Number of } \\
\text { patients }\end{array}$ & $\mathbf{\%}$ \\
\hline $\mathbf{1}$ & MI & 38 & 35.5 \\
\hline $\mathbf{2}$ & underwent PCI & 7 & 6.5 \\
\hline $\mathbf{3}$ & underwent CABG & 14 & 13.1 \\
\hline $\mathbf{4}$ & PVD & 8 & 7.5 \\
\hline $\mathbf{5}$ & CVD & 11 & 10.3 \\
\hline
\end{tabular}

Table 4. TIMI risk score

\begin{tabular}{|l|l|l|}
\hline TIMI risk score & Number of patients & \% \\
\hline 0 & 1 & 0.9 \\
\hline 1 & 10 & 9.3 \\
\hline 2 & 22 & 20.6 \\
\hline 3 & 24 & 22.4 \\
\hline 4 & 27 & 25.2 \\
\hline 5 & 17 & 15.9 \\
\hline 6 & 5 & 4.7 \\
\hline 7 & 1 & 0.9 \\
\hline
\end{tabular}

Table 4.1. TIMI risk score scale

\begin{tabular}{|l|l|l|}
\hline TIMI risk score scale & Number of patients & $\%$ \\
\hline Low (1-2) & 33 & 30.8 \\
\hline Intermediate (3-4) & 51 & 47.6 \\
\hline High (5-7) & 23 & 21.5 \\
\hline
\end{tabular}

Table 5. Outcomes after 14 days

\begin{tabular}{|l|l|l|}
\hline Outcome & Number of patients & \% \\
\hline Death & 3 & 2.8 \\
\hline Myocardial infarction & 3 & 2.8 \\
\hline Recurrent pain & 30 & 28 \\
\hline Without adverse event & 70 & 65.4 \\
\hline No data & 1 & 0.9 \\
\hline
\end{tabular}

The distribution of previous cardiovascular disease is shown in Table 3. Overall, 72.9\% (78) of patients suffered from previous cardiovascular disease, among whom $35.5 \%$ (38) had MI, 6.5\% (7) underwent PCI, 13.1\% (14) underwent CABG, 7.5\% (8) had PVD and 10.3\% (11) had CVD.

\section{TIMI risk score}

The number of patients with a different TIMI risk score was significantly different in the different groups (c2-test; $\mathrm{p}=0.000$ ). The most common risk score was four - in $25.2 \%$ of patients. The low-risk group (TIMI 0 - 2) included $30.8 \%$ of patients, whereas $47.6 \%$ of patients were in the intermediate-risk group (TIMI $3-4$ ), and $21.5 \%$ of patients were in the high-risk group (TIMI 5 - 7) (Table 4). Moreover, 36 out of 107 patients (34.6\%) had poor outcomes (recurrent pain in the chest, myocardial infarction, death) (Table 5). Among them, $25 \%$ of patients were in the low-risk group (TIMI $1-2), 41.7 \%$ of patients were in the intermediate-risk group (TIMI 3-4), and $33.3 \%$ of patients were in the high-risk group (TIMI 5-7) (Table 4.1).

\section{Clinical outcome}

Based on multivariate binary logistic regression (Table 6 ), it was found that the outcomes werewas dependent on the TIMI risk score $(\mathrm{p}=0.015)$. An increase in the TIMI risk score per 1 unit increased the risk of a poor outcome by $40.3 \%$, with an odds ratio of 1.403 (1.026 - 1.918).

\section{DISCUSSION}

Patients with APns/NSTEMI can have a good prognosis with pharmacologic therapy if they are in the low-risk group, or they may require more aggressive antithrombotic and invasive (PCI) therapy if they are in the high-risk group. Clinical indications of an increased risk of a fatal event in patients with APns/NSTEMI include anamnesis, clinical presentation, ECG, laboratory analysis, and coronary angiogram results (4-7). There are many methods of calculating the risk of a new cardiovascular event. In the stratification of high-risk patient groups, several scores arewere used (GRACE, PURSUIT, TIMI, HEART). All of them have virtually the same predictive value in short-term observation, whereas in long-term observation, the most valid are the GRACE score (includes heart failure, which is very common in practice) and PURSUIT score (follows the creatinine value) (8). The GRACE risk score (based on clinical presentation) is a consequence of the PURSUIT study, which has proven increased mortality in the following patients: elderly people and patients with hypotension, tachycardia, ST-segment depression, signs of heart failure and higher levels of markers of myocardial necrosis (9-11).

We showed that the risk of a poor outcome (death, myocardial infarction, recurrent chest pain) was increased by $54.1 \%$ (odds ratio 1.541, table 6) when the TIMI risk score increased per one unit, which indicated the significance of the TIMI risk score in the stratification of patients with unstable angina pectoris. The TIMI risk score was chosen due to its simple usage at admission and during short-term observation to confirm that high-risk patients have poorer outcomes (14 days after hospitalization). Consistency in applying the recommended treatment measures is increased by the isolation of high-risk patients: required hospitalization, dual anti-platelet therapy, LMWH rather than UFH, Gp IIb/IIIa inhibitors, emergent/early invasive therapy as opposed to medical therapy, regular check-ups and stricter control of heart risk factors due to poorer long-
Table 6. Univariate and multivariate binary regression

\begin{tabular}{|l|l|l|l|l|}
\hline & \multicolumn{2}{|l|}{ Univariate binary regression } & \multicolumn{2}{l|}{ Multivariate binary regression } \\
\hline Variable & Odds ratio & $\mathrm{p}$ & Odds ratio & $\mathrm{p}$ \\
\hline TIMI risk score & $1.376(1.020-1.856)$ & 0.036 & $1.541(1.089-2.180)$ & 0.015 \\
\hline
\end{tabular}


term prognosis (12). Moreover, $69.1 \%$ of our patients had a TIMI risk score $\geq 3$, whereas $21.5 \%$ of patients were in the high-risk group (TIMI $5-7$ ).

It should be emphasized tht comparedison with other previously reported scores, the TIMI risk score possesses an equal predictive value to that of GRACE or PURSUIT in short-term observation. However, TIMI can be constructed at admission (within the first hours of hospitalization) because it simple and does not require the clinical status of the patient. Otherwise, the GRACE score is primarily used in clinical practice and involves following the clinical status of the patient; thus, it is more reliable in long-term observation (2). Thus, it is obvious that the TIMI risk score is the most prompt stratification testand is and is particularly convenient for the emergency department.

The EXTRACT-TIMI 25 trial with enoxaparin in patients with APns/NSTEMI has shown a decrease in mortality, myocardial infarction and recurrent ischaemia by $20 \%$ compared with UFH, especially in patients with STsegment depression, higher levels of troponin I (with normal CK-MB values) and TIMI risk scores $\geq 3$ (13).

The present results indicate that (higher) TIMI scores affect the type of therapy. Namely, in our study, every tenth patient was treated with enoxaparin, although the TIMI risk score was $\geq 3$, which was a consequence of the high price of enoxaparin.

In the TACTIS-TIMI 18 study, patients were treated with aspirin, heparin and the GP IIb/IIIa inhibitor tirofiban. Early invasive therapy (up to 48 hours) showed a benefit in patients with ST-segment changes $(10 \%$ absolute risk reduction) and with positive troponin (39\% risk reduction). The patients who benefited most from early invasive therapy were those with intermediate- (3-4) and high-risk (5-7) TIMI scores (14).

In the FRISC II study, 2457 patients with APns/NSTEMI were treated conservatively, or their arteriography was postponed because they had refractory angina (despite maximal anti-anginal therapy) or a positive cardiac stress test with ST-segment depression $\geq 0.3 \mathrm{mV}$ within the first four days of symptom onset. Only $9 \%$ of patients fulfilling these criteria were treated with revascularization within a period of seven days. Six months later, the risk of death or myocardial infarction was significantly decreased in the group that received invasive therapy $(9.4 / 12.1 \%)$ and was stable after one year (2.2/3.9\%) (15).

The conditions of all patients with a TIMI risk score $\geq 3$ (two-thirds of the patients in our study) improved after early invasive therapy; hence, medical wards for arteriography should be made more accessible, at least for highrisk patients.

In the short-term observation of patients with unstable angina (within 14 days of their hospitalization), 33.6\% had poor outcomes, including death, myocardial infarction or recurrent pain. Most of these patients had recurrent chest pain; $28 \%$ showed signs of acute coronary disease instability (Table 5).
A positive correlation between TIMI risk score and troponin values indicated that patients with angina pectoris and borderline troponin values have an increased risk of a poor outcome, which may be an additional benefit of the utilization of the TIMI risk score.

\section{CONCLUSION}

The present study noteddemonstrated that the TIMI risk score was a reliable predictor of a poor outcome in the short-term observation of patients with unstable angina pectoris. The TIMI risk score is the most prompt stratification testand is and is particularly convenient for the emergency department. A high TIMI risk score, which can be determined as soon as the patient is hospitalized, determines the course of subsequent treatments.

\section{REFERENCES:}

1. Fernandez-Berges D, Bertomeu-Gonzalez V, Sanchez PL, Cruz-Fernandez JM, Arroyo R, Barriales Alvarez V, Carrasco Sanchez FJ, Dalli E, Castro Beiras A, Kaski JC. (2011). Clinical scores and patient risk stratification in non-ST elevation acute coronary syndrome. Int J Cardiol. 146: 219-224.

2. De Aralijo Goncalves P, Fereira J, Aguiar C, Seabra-Gomes R. (2005). TIMI, PURSUIT and GRACE risk scores: sustained prognostic value and interaction with revascularisation in NSTE-ACS. Eur Heart J. 26: 865-872.

3. Aragam KG, Tamhane UU, Kline-Rogers E, Li J, Fox KA, Goodman SG, Eagle KA, Gurm HS. (2009). Does simplicity compromise accuracy in ACS risk prediction? A retrospective analysis of the TIMI and GRACE risk scores. PLoS One. 4: e7947.

4. Ang DS, Wei L, Kao MP, Lang CC, Struthers AD. (2009). A comparison between B-type natriuretic peptide, global registry of acute coronary events (GRACE) score and their combination in ACS risk stratification. Heart. 95: 1836-1842.

5. Pencina MJ, D’Agostino RB Sr, Steyerberg EW. (2011). Extensions of net reclassification improvement calculations to measure usefulness of new biomarkers. Stat Med. 30: 11-21.

6. Schiele F, Meneveau N, Seronde MF, Chopard R, Descotes-Genon V, Dutheil J, Bassand JP. (2010). C-reactive protein improves risk prediction in patients with acute coronary syndromes. Eur Heart J. 31: 290-297.

7. Eggers KM, Lagerqvist B, Venge P, Wallentin L, Lindahl B. (2009). Prognostic value of biomarkers during and after non-ST-segment elevation acute coronary syndrome. J Am Coll Cardiol. 54: 357-364.

8. Carruthers KF, Dagbous OH, Flather MD, Starkey I, Jacob A, MacLeod D et al. (2005). behalf of the GRACE investigators. Contemporary management of acute coronary syndromes: does the practice match the evi- 
dence? The global registry of acute coronary events (GRACE). Heart. 91: 290-298.

9. Yan AT, Yan RT, Huynh T, Casanova A, Raimondo FE, Fitchett DH, Langer A, Goodman SG. (2009). Understanding physicians' risk stratification of acute coronary syndromes: insights from the Canadian ACS 2 Registry. Arch Intern Med. 169: 372-378.

10. Gale CP, Manda SO,Weston CF, Birkhead JS, Batin PD, Hall AS. (2009). Evaluation of risk scores for risk stratification of acute coronary syndromes in the Myocardial Infarction National Audit Project (MINAP) database. Heart. 95: 221-227.

11. Morrow DA (2010). Cardiovascular risk prediction in patients with stable and unstable coronary heart disease. Circulation. 121: 2681-2691.

12. Mehta SR, Granger CB, Boden WE, Steg PG, Bassand JP, Faxon DP, Afzal R, Chrolavicius S, Jolly SS, Widimsky P, Avezum A, Rupprecht HJ, Zhu J, Col J, Natarajan MK, Horsman C, Fox KA, Yusuf S. (2009). Early versus delayed invasive intervention in acute coronary syndromes. N Engl J Med. 360: 2165-2175.

13. Morrow DA, Antman EM, Fox KA, Knite HD, Giuliano R, Myrphy SA, McCabeand CH, Braunwald E. (2010). One-year outcomes after a strategy using enoxaparin vs. unfractionated heparin in patients undergoing fibrinolysis for ST-segment elevation myocardial infarction: 1-year result of the EXTRACT-TIMI 25 trial. Eur Heart J. 31: 2097-2102.

14. McCullough PA, Gibson CM, DiBattiste PM, et al. (2004). For the TACTIS TIMI-18 Investigators: Timing of angiography and revascularisation in acute coronary syndromes: An analysis from the TACTIS TIMI-18 trial. J Interv Cardiol. 17: 81.

15. Diderholm E, Andren B, Frostfeldt G et al. (2002). The prognosticand therapeutic implications of increased troponin levels and ST depresion in unstable coronary artery disease: the FRASC II invasive troponin T electrocardiogram sybstudy. Am Heart J. 143: 760-767. 
둥 